\title{
Elastin-like polypeptide fusions enhance the accumulation of recombinant protein in tobacco leaves
}

\author{
Jignasha Patel $\cdot$ Hong Zhu $\cdot$ Rima Menassa $\cdot$ \\ Laszlo Gyenis · Alex Richman · Jim Brandle
}

Published online: 15 February 2007

(C) Springer Science+Business Media B.V. 2007

\section{Erratum to: Transgenic Res DOI: 10.1007/s11248-006-9026-2}

Due to an unfortunate technical error during the production process of the above mentioned article, the figure caption of Fig. 5 has been duplicated and also used for Fig. 6. The correct representation of Fig. 6 and its caption has been published on this page and should be treated as definitive by the reader.

The online version of the original article can be found at http://dx.doi.org/10.1007/s11248-006-9026-2

J. Patel · H. Zhu · R. Menassa - L. Gyenis .

A. Richman · J. Brandle $(\bowtie)$

Agriculture and AgriFood Canada, Southern Crop

Protection and Food Research Center, 1391 Sandford

Street, London, Ontario N5V 4T3, Canada

e-mail: brandleje@agr.gc.ca

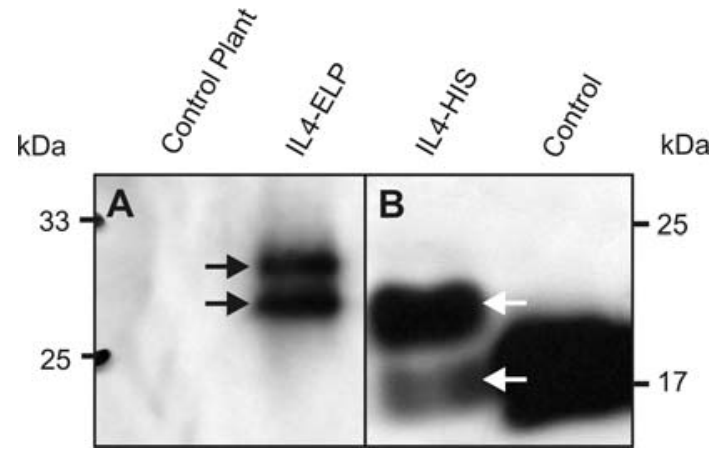

Fig. 6 Western analysis of interleukin-4 protein. (A) Immunoprecipitated from untransformed $81 \mathrm{~V} 9$ control plants (lane 1) and from IL4-ELP transgenic plants (lane 2) protein and (B) IMAC purified IL4-HIS from crude protein extracts of agroinfiltrations of $81 \mathrm{~V} 9$ leaves with IL4-HIS (lane 1) and recombinant murine IL4 control protein (lane 2). The arrow heads mark the position of the target protein 